\title{
Erratum to: Aquifer vulnerability and groundwater quality in mega cities: case of the Mexico Basin
}

\author{
Jose Alfredo Ramos Leal · C. Noyola Medrano • \\ F. O. Tapia Silva
}

Published online: 24 February 2010

(C) Springer-Verlag 2010

\section{Erratum to: Environ Earth Sci}

\section{DOI 10.1007/s12665-009-0434-5}

The original version of this article unfortunately contained some mistakes. The presentation of Eqs. 6 and 7 was incorrect. The correct versions are given below.

$$
\begin{aligned}
& \mathrm{WQI}=k \frac{\sum C_{i} P_{i}}{\sum P_{i}} \\
& \mathrm{CI}=\sum_{i=1}^{n} C_{\mathrm{f} i}
\end{aligned}
$$

The last sentence of paragraph "Defining parameters for SINTACS" should read "WQI indices range from 0 to 100 , and some authors have defined quality scales as indicated in Table 4".

In the tablehead of Table 4, it should read "WQI scale" instead of "ICA scale".

The online version of the original article can be found under doi:10.1007/s12665-009-0434-5.

\section{J. A. Ramos Leal $(\bowtie) \cdot$ C. Noyola Medrano}

Instituto Potosino de Investigación Científica y Tecnológica, A.C. (IPICYT), C. Presa San Jose \# 2055, Lomas $4^{\mathrm{a}}$ Sección, 78216 San Luís Potosí, SLP, Mexico

e-mail: jalfredo@ipicyt.edu.mx

\section{Noyola Medrano}

Division de Ingenierias, Depto. de Ingeniería Geomática e Hidráulica, Universidad de Guanajuato, Av. Juárez No. 77,

Centro, 36000 Guanajuato, Gto, Mexico

F. O. Tapia Silva

Centro de Investigación en Geografía y Geomática "Ing. Jorge

L. Tamayo" A.C., Contoy No. 137, Col. Lomas de Padierna

Delegación Tlalpan, 14740 México, D.F., Mexico 